Prepared for the U.S. Department of Energy under Contract DE-AC05-76RL01830

\title{
U.S. Federal Investments in Energy R\&D: 1961-2008
}

JJ Dooley

October 2008

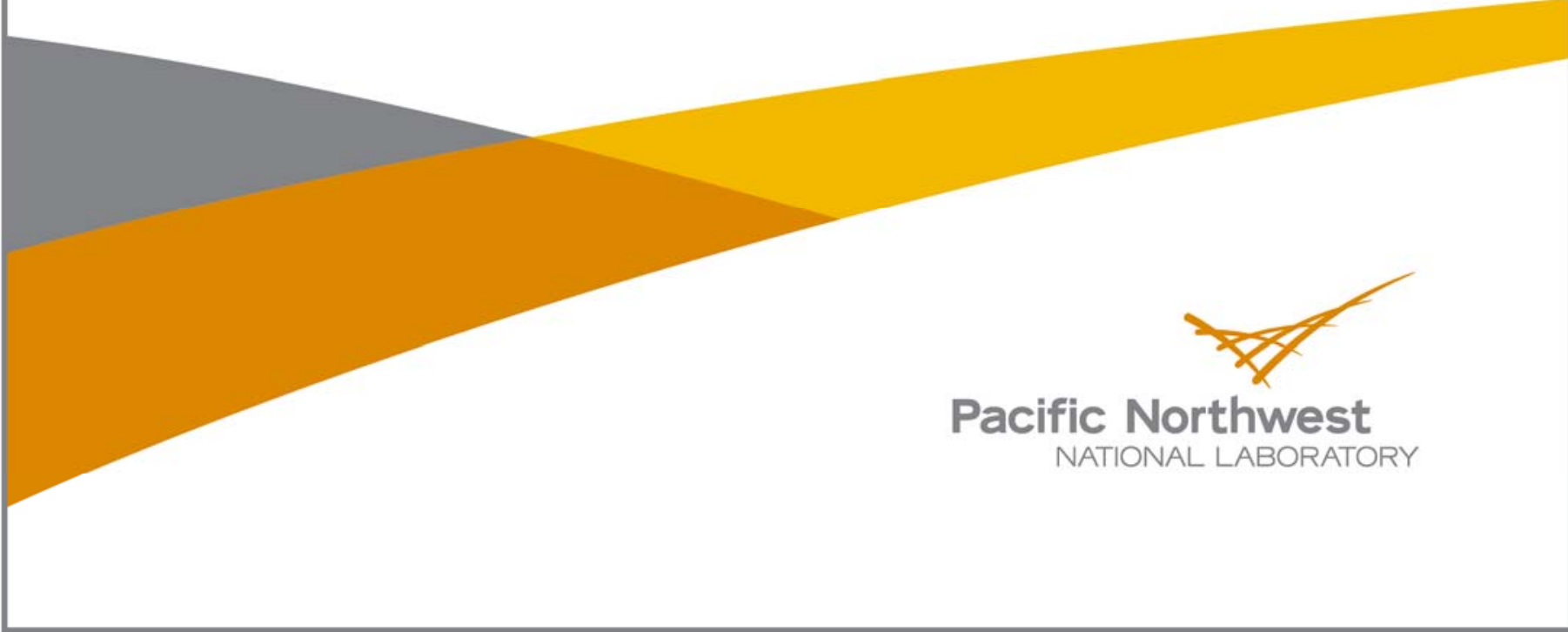




\title{
DISCLAIMER
}

This report was prepared as an account of work sponsored by an agency of the United States Government. Neither the United States Government nor any agency thereof, nor Battelle Memorial Institute, nor any of their employees, makes any warranty, express or implied, or assumes any legal liability or responsibility for the accuracy, completeness, or usefulness of any information, apparatus, product, or process disclosed, or represents that its use would not infringe privately owned rights. Reference herein to any specific commercial product, process, or service by trade name, trademark, manufacturer, or otherwise does not necessarily constitute or imply its endorsement, recommendation, or favoring by the United States Government or any agency thereof, or Battelle Memorial Institute. The views and opinions of authors expressed herein do not necessarily state or reflect those of the United States Government or any agency thereof.

\author{
PACIFIC NORTHWEST NATIONAL LABORATORY \\ operated by \\ BATTELLE \\ for the \\ UNITED STATES DEPARTMENT OF ENERGY \\ under Contract DE-AC05-76RL01830
}

Printed in the United States of America
Available to DOE and DOE contractors from the Office of Scientific and Technical Information,
P.O. Box 62, Oak Ridge, TN 37831-0062;
ph: (865) 576-8401
fax: $(865)$ 576-5728
email: reports@adonis.osti.gov

\begin{abstract}
Available to the public from the National Technical Information Service, U.S. Department of Commerce, 5285 Port Royal Rd., Springfield, VA 22161 ph: (800) 553-6847 fax: $(703) 605-6900$ email: orders@ntis.fedworld.gov online ordering: http://www.ntis.gov/ordering.htm
\end{abstract}

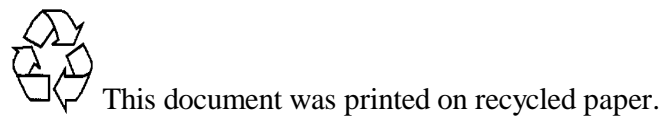




\begin{abstract}
This paper documents nearly a half century of U.S. federal government support for energy research and development (R\&D). Data on energy R\&D expenditures disaggregated by major program area are presented here for the first time for the period 1961-2008. This paper also documents U.S. federal government spending on key large scale energy R\&D programs that were initiated in response to the oil crisis of the 1970s. Since 1961, the U.S. government has invested nearly $\$ 172$ billion (in inflation adjusted 2005 US dollars) for the development of advanced energy technologies and for the necessary underlying basic science. Over this period, nearly $24 \%$ of the total federal investment in energy R\&D occurred during the short seven-year span of 1974-1980. From 1977-1981, energy R\&D investments briefly rose above $10 \%$ of all federal R\&D; however, since the mid-1990s energy R\&D has accounted for only about $1 \%$ of all federal R\&D investments.
\end{abstract}

KEY WORDS: energy R\&D; United States Government; energy technology. 


\section{Introduction}

This paper documents nearly a half century of U.S. federal government support for energy research and development (R\&D), occurring between 1961 and 2008. The purpose of this paper is to assess significant trends in energy R\&D investment, which is an important but limited input measure that can shed some light on observed rates of change in energy technology. This information may help to inform pressing questions surrounding the adequacy of current efforts to develop energy technology, particularly in response to technologically-intensive challenges such as climate change.

However, it is important to note that it is not the intent of this paper to analyze the fruits of these federal investments, nor to look in great detail at how individual energy R\&D programs have evolved and changed focus over this period of time. Retrospective assessments of the return on investment related to federal government support for energy R\&D in general and for specific programs (principally but not exclusively supported by the U.S. Department of Energy) have been completed by others. ${ }^{1}$

\section{Federal Energy R\&D in the Context of the Overall Federal R\&D Enterprise}

Between 1961-2008, the U.S. federal government has cumulatively invested nearly $\$ 4$ trillion dollars in R\&D (NSF 2007). ${ }^{2}$ Figure 1 shows how the relative emphasis placed on various fields of research has changed with time. For all but one year (1979), defense R\&D has accounted for at least half of all federal R\&D investments. During the "space race" of the 1960s, space R\&D (principally at NASA) accounted for as much as one-third of all federal R\&D. Beginning in the mid-1990s, health R\&D started to account for anywhere between one-fifth and one-quarter of all federal R\&D investments.

Except for the brief period from 1977-1981, during which energy R\&D investments rose above $10 \%$ of all federal R\&D, investments in energy R\&D have comprised a small fraction of overall spending. Since the mid-1990s energy R\&D has accounted for approximately $1 \%$ of all federal R\&D investments.

\footnotetext{
${ }^{1}$ For example in its 2001 assessment of the Department of Energy's energy efficiency and fossil energy R\&D programs, the National Academy of Sciences concluded that "the net realized economic benefits [to the U.S. economy as a whole] in the energy efficiency and fossil energy [R\&D] programs were judged ... to be in excess of the DOE investment" (NRC, 2001). Other examples of these retrospective studies of federal investments in energy R\&D include: OTA 1975, Cohen LR and Noll RG. 1991, Yergin, et. al. 1995, PCAST 1997, GAO 2006.

${ }^{2}$ All financial data in this report are reported in inflation-adjusted, real 2005 U.S. dollars unless otherwise noted. The conversion of current, nominal, as-spent dollars (which is how most of these data are reported in the original source materials) to inflation-adjusted 2005 U.S. dollars was computed by using Gross Domestic Product Price Deflators taken from CEA, 2006.
} 


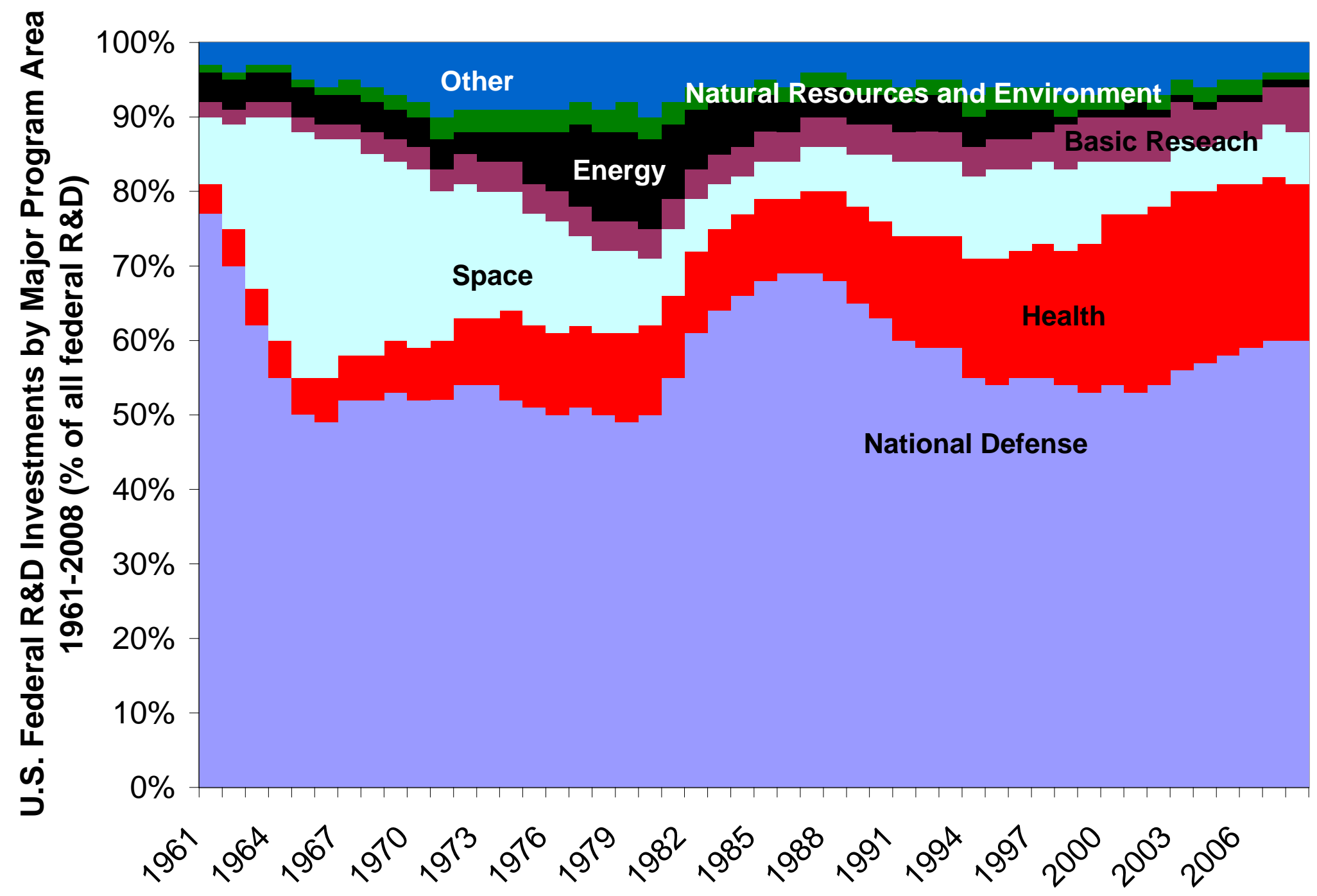

Figure 1: U.S. Federal Government Investments in R\&D by Major Area of Focus 


\section{Trends in Federal Energy R\&D: 1961-2008}

The federal government has invested approximately $\$ 172$ billion dollars in energy R\&D activities during the period 1961-2008. Figure 2 displays cumulative federal energy $\mathrm{R} \& \mathrm{D}$ investments aggregated by major program for the period 1961-2008.

Nuclear energy R\&D (including both fission and fusion related energy R\&D) represents the largest component at slightly more than $36 \%$ of this cumulative investment $\$ \$ 61$ billion). The Other Energy R\&D program area (principally Basic Energy Research and similar basic science programs intended to support the more applied energy technology R\&D programs) accounts for 34\% ( $\$ 60$ billion) of this cumulative investment. The remaining 30\% of the cumulative federal energy R\&D investment from 1961-2008 is split evenly ( $\$ 26$ billion each) between fossil energy R\&D and the combination of renewable and energy efficiency R\&D.

Quantitative data on federal investments in energy R\&D prior to 1961 are not readily available. However, a number of lines of evidence suggest that support for energy R\&D prior to 1961 was quite limited in scope (almost exclusively focused on nuclear energy) ${ }^{3}$ and in terms of resources devoted to these activities.

Given the lack of a robust quantitative data set on federal energy R\&D expenditures prior to 1961 , the remainder of this paper will focus on analyzing trends in federal support for R\&D starting with 1961. Figure 3 provides a more detailed view of the annual federal investments in energy R\&D for the period 1961-2008. It clearly shows that the portfolio of energy R\&D activities sponsored by the federal government has changed significantly over the past half century. Not only has the size of the federal energy R\&D portfolio changed but its composition has evolved as well.

Federal support for energy R\&D over the period 1961-2008 can be subdivided into a rather small handful of largely distinct periods each characterized by the following apparent funding priorities.

\footnotetext{
${ }^{3}$ For example, Schultze et al. 1971 state that the first federal efforts related to what would now be termed energy R\&D outside the realm of nuclear power stem from legislation passed in 1955 that authorized "modest appropriations for research, data collection, and technical assistance to state and local governments" due to rising concern about air pollution from automobiles and fossil fired power plants. An official Environmental Protection Agency history of the Clean Air Act makes it clear that Shultz was referring to the Air Pollution Act of 1955 which authorized modest funding for research to identify the sources of air pollution (EPA 2008).
} 


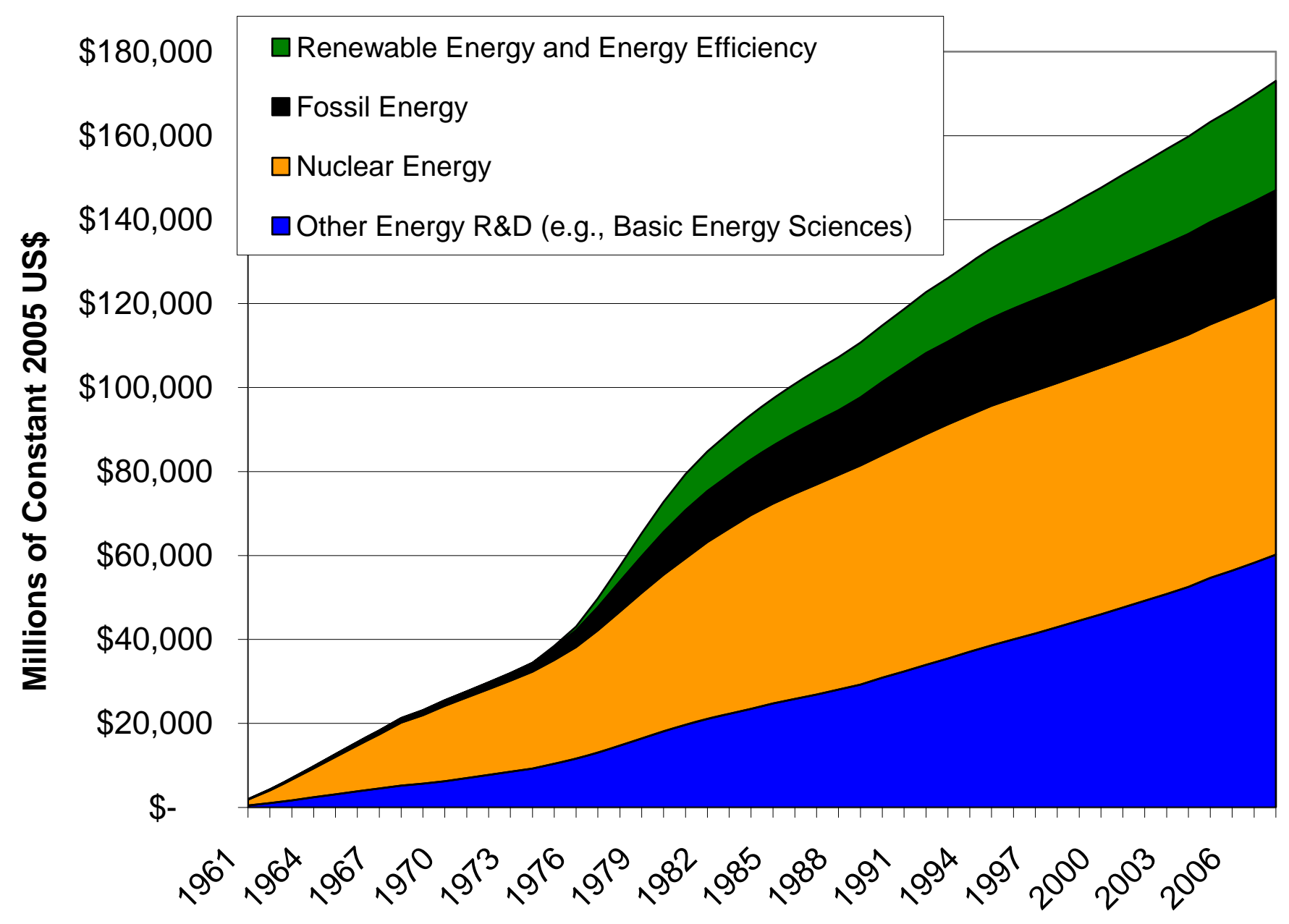

Figure 2: Cumulative Federal Investments in Energy R\&D 1961-2008 (Constant 2005 U.S.\$) 


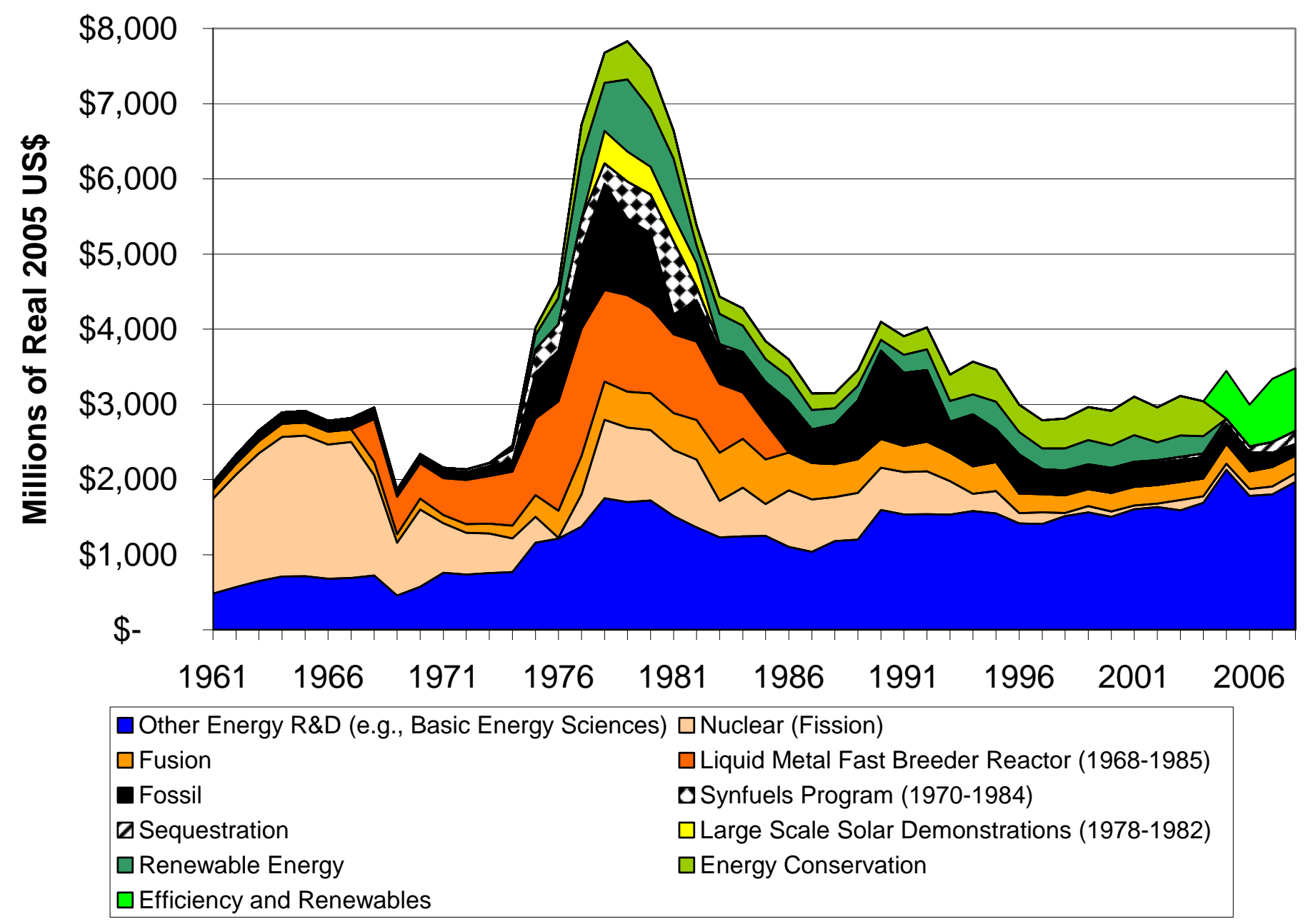

Figure 3: Annual Federal Energy R\&D Investments by Major Program Area 1961-2008 (Millions of Real 2005 U.S.\$) 
1961-1973: Federal energy R\&D was dominated by nuclear energy R\&D (e.g., during the 1960s nuclear energy R\&D accounted for more than $70 \%$ of all federal energy R\&D investments). Other non-nuclear energy $R \& D$ programs during this time frame were quite small. According to Fehner and Hall (1994), these non-nuclear energy R\&D programs were "scattered throughout the federal departments and agencies and reflected the government's benign approach to energy management as a whole".

From Figure 3, it is clear that nuclear fission energy R\&D was the overwhelming focus of federal energy $R \& D$ efforts during this period. The federal nuclear energy $R \& D$ program was dominated by R\&D for new reactor designs, improved uranium enrichment technologies, and on improving reactor safety. Cohen and Noll (1991) note that during the 1950s and 1960s the dominance of nuclear energy R\&D as the central focus of federal energy R\&D was well understood. In large measure, this stemmed from the federal government's virtual monopoly on knowledge relating to fission and fusion reactions which flowed from the nation's nuclear weapons program. Cohen and Noll (1991) report that by 1967 the Atomic Energy Commission's "Light-Water Reactor Development Program was largely finished and was hailed as a success" as electric utilities started to order commercial light water reactors. By 1963, the Jersey Central Power and Light company announced the first nuclear power plant in the U.S. selected purely on economic grounds (i.e., without government aid). By 1967, U.S. electric utilities had ordered 75 base load light water nuclear reactors (Fehner and Hall, 1994). The apparent commercial success of light water reactors led to a major refocusing of the federal government's nuclear energy $R \& D$ programs towards the development of breeder reactors due to widespread concern amongst experts at the Atomic Energy Commission and elsewhere at the time that global uranium supplies were limited and a switch to breeder reactors was the only way of ensuring the continued viability of nuclear power (Fehner and Hall, 1994). Federal support for fusion energy R\&D composed approximately $10 \%$ of the federal energy effort during this period (Hammond, Metz, and Maugh, 1973),

There was also during this period a small federal research program related to coal. While funding for coal related energy R\&D would expand dramatically in the 1970s, during the period 1961-1969, the energy R\&D budget of the federal Office of Coal Research averaged \$6 million per year (in current, as spent dollars) and this Office had less than two dozen employees (Cohen and Noll, 1991).

During this period, the first appropriations were made for R\&D directed at controlling air pollution resulting from the combustion of fossil fuels from stationary and mobile sources. The Air Quality Act of 1967 authorized the Department of Health, Education and Welfare to "initiate and accelerate a national research and development program to achieve the prevention of and control of air pollution" (P.L. 90-148). The Act contained appropriations of \$35 million these R\&D activities in 1968 and \$90 million for 1968 (in current, as spent dollars). While these funds created a national energy R\&D program to 
deal with urban smog were significantly more than what had been allocated to date, these were still relatively small components of the overall federal energy R\&D enterprise. ${ }^{4}$

Hammond, Metz, and Maugh (1973) writing in the Spring of 1973 in the wake of what they -at the time - saw as a series of significant "energy crises" such as the great blackout of 1965 in which approximately 25 million lost power in the North East, reoccurring brownouts in 1971, and a shortage of heating oil in the winter of 1972 pointed to what they say as evidence that energy policy and energy R\&D were simply not national priorities:

How did the energy crisis catch us unaware? One answer is that the system worked so well that until the mid-1960's no one paid any attention to where things were going. In both public and private decision making, most people acted as if ever increasing amounts of energy at ever lower prices would always be available - and the fallacy of this assumption is now apparent (Hammond, Metz, and Maugh, 1973).

This expectation of cheap and abundant energy supplies was also seen by these authors as a key reason why society had not invested sufficiently in advanced energy technologies which could have averted these pre-Arab Oil Embargo energy crises. Their critique of the 1973 federal energy R\&D effort was that it "reflects to a large extent past attitudes on energy priorities. In retrospect, it seems that the neglect of research on coal technologies in the last 20 years is a major cause of present fuel and electricity shortages."

1974-1980: The Arab Oil Embargo which began on October 19, 1973 sparked a fundamental reassessment of the nation's vulnerability to imported energy and also forced a reassessment of the role that energy $R \& D$ could play in helping secure the nation against hostile acts like the Oil Embargo.

Federal investments in energy R\&D more than doubled in real terms in the short interval between 1973-1976 and nearly doubled again between 1976-1980. Federal investments in energy R\&D rose from $\$ 2.45$ billion in 1974 to $\$ 7.47$ billion in 1980 (in constant, inflation adjusted 2005 US\$). The largest absolute gains were in the fossil energy R\&D programs which grew an order of magnitude in real terms during this period rising from $\$ 143$ million in 1974 to $\$ 1.41$ billion in 1979 . The Synfuels Program grew more than 3.5 times in real terms during this period. Nuclear energy programs also saw significant absolute growth during this period. For example, the Liquid Metal Fast Breeder Reactor program's annual appropriations grew by slightly more than a billion dollars between 1973 and 1977 (increasing from $\$ 643$ million to $\$ 1.69$ billion during these five years).

\footnotetext{
${ }^{4}$ President Johnson noted how significant a jump in funding for air pollution R\&D and other measures (e.g., grants to states and cities to develop and implement air pollution control programs) when he signed the Air Quality Act of 1967 noting that "In the next 3 years, it will authorize more funds to combat air pollution than we have spent on this subject in the entire Nation's history of 180 years" (Johnson, 1967).
} 
In the immediate aftermath of the 1973 Oil Embargo, not only did federal investments in energy R\&D grow dramatically in areas like coal and nuclear power where it had already established programs, the portfolio of federal energy $R \& D$ activities also became significantly broader and more diversified. That is, the broadly diversified federal energy $R \& D$ portfolio of that has been in place for decades and is often taken for granted as an obvious way to organize the government's efforts to develop new energy technologies emerged in response to the chaos caused by the energy crises more than 30 years ago.

- The first federal solar, geothermal and energy conservation programs were started in 1974 (Stewart, et al., 1983). ${ }^{5}$ These programs accounted for $2.5 \%$ of federal energy R\&D in 1974 although their budgets and the priority accorded to them would grew dramatically in response to the Arab Oil Embargo. Federal spending on renewable energy grew 42 fold in real terms from \$32 million in 1974 to \$1.36 billion in 1979 .

- According to official budget documents from the Office of Management and Budget it was not until 1974 that there were any outlays for a dedicated federal energy efficiency $R \& D$ program $(O M B, 2006)$. This federal energy efficiency $R \& D$ program started out with a modest $\$ 29$ million in 1974 and quickly expanded to \$511 million in 1979 (in constant inflation adjusted 2005 US\$).

It is also important to note that in this crisis atmosphere the federal government interpreted its mandate with respect to energy technology development as going beyond the bounds of research, development and one-of-a-kind, small pilot facilities. For example in 1975, President Ford called for the creation of a national Energy Independence Authority that would "assist in the construction of nuclear power plants, coal-fired power plants, oil refineries, synthetic fuels plants, and other energy production facilities" (Fehner and Hall, 1994).

This same emphasis on moving towards commercial activities comes out clearly in an analysis of the energy R\&D efforts of the newly created Energy Research and Development Authority (ERDA) performed by the Office of Technology Assessment (OTA) at the request of the United States Congress. OTA's critique of the federal fossil energy R\&D program clearly indicates that the idea of the federal government becoming far more involved in the creation and production of energy along the lines outlined by President Ford. The OTA analysis stated that:

By focusing on new technologies, the fossil fuel program (contrary to the supply projections contained in it) limits itself to an insignificant impact on energy supplies in the short-term- before 1985... The first priority should be to get better information about presently available technologies and to facilitate their

\footnotetext{
${ }^{5}$ To be more precise, the first significant federal solar energy programs designed for terrestrial applications were started in the early 1970s. Cohen and Noll (1991) estimate that federal R\&D for terrestrial solar energy applications averaged less than $\$ 100,000$ (in current, then year dollars) between 1950-1970 in a program that was run out of the National Science Foundation. Cohen and Noll (1991) note that federal support for photovoltaic R\&D goes back to at least 1958 when photovoltaic cells were used to provide power for the Vanguard satellite, which was launched on March 17, 1958.
} 
use when feasible: It must be recognized that the era of abundant cheap energy is over-especially in the cases of liquid and gasfuels. Because of the urgency of the national energy situation, the ERDA fossil-fuel program should emphasize the demonstration of available technologies" at an appropriate scale (OTA 1978).

The OTA analysis also suggested that the federal effort to develop photovoltaic technologies was misplaced given the nation's urgent need for increased domestic energy production and recommended that the solar program focus instead on solar water and space heating which were technologically and economically "available now" (OTA 1978).

This push to move the federal government far closer to what would now be viewed as commercial activities were not merely hypothetical suggestions but were ideas that enjoyed broad bipartisian support and which were put into practice. The clearest examples of this can be seen in the rise of very large programs designed to develop and build synfuels facilities, significant federal programs to deploy solar energy technologies, and significant rapid growth in resources devoted to developing nuclear power production technologies:

- The cumulative federal investment in the Synfuels Program (1970-1984) was approximately $\$ 4$ billion (in 2005 US\$)

- The federal government's cumulative investment in the short-lived Large-Scale Solar Demonstrations Program (1978-1982) was approximately \$2 billion.

- The cumulative federal investment in the development of breeder reactors 19681985 was nearly $\$ 16$ billion (almost 10\% of all federal R\&D invested between 1961-2008).

While these programs' lives extend beyond the period 1974-1980, the majority of their expenditures were incurred during this period and the ramp up in their budgets was clearly a response to the sense of urgency caused by concerns over U.S. dependence on imported oil during this time frame. Perhaps of more significance is to note that $24 \%$ of all federal energy R\&D investments made during the near half century from 1961-2008 occurred during this short seven-year period from 1974-1980.

1981-1988: During the period, 1981-1998, federal energy R\&D expenditures fell by more than 50\% in real terms. Federal support for energy R\&D fell from $\$ 6.64$ billion in 1981 to 3.15 billion in 1988. During this period, a number of high profile energy technology development programs such as the breeder reactor program, the synfuels program and the program of large scale solar energy demonstrations were all terminated. This occurred during the Reagan Administration, which maintained that "only in areas where these market forces are not likely to bring about desirable new energy technologies 
and practices within a reasonable amount of time is there a potential need for federal involvement (emphasis added)." 6

This significant reframing of what were judged to be appropriate activities for the US Department of Energy to undertake was also reflected more broadly. For example, in early 1983 the DOE's own Energy Research Advisory Board (ERAB) published a report outlining a series of criteria for the federal government investment in specific energy $\mathrm{R} \& \mathrm{D}$ projects or programs (ERAB, 1983). ERAB directed federal energy R\&D program managers before committing public funds to energy $R \& D$ projects to assess whether the private sector was believed to be doing similar research, the degree of risk associated with the research (i.e., the government should only be doing high risk research) or whether there was a specific federal regulatory need for the research (e.g., nuclear safety related energy R\&D sponsored by the Nuclear Regulatory Commission). The net effect of this was to significantly narrow what the accepted appropriate federal role for federal energy research was to be.

Of particular importance was ERAB's explicit endorsement of using the private sector's willingness to provide significant cost share as the central criteria for assessing whether there is an appropriate role for the federal government to support more applied energy R\&D. ERAB was explicit that it "must be more than just a 'token' private contribution" as the willingness of the private sector to put up significant cost share "is a far more reliable criterion than the often quite inaccurate and unreliable 'appraisals' commissioned by DOE or private sponsors to justify projects where many of the resulting economic estimates are suspect." (ERAB, 1983).

ERAB then applied these criteria to the DOE's existing and proposed energy technology budgets and in doing so called for the complete elimination of federal support for two energy technology programs (hydroelectric power and magnetohydrodynamics) as well as considerable reductions in more than half of the ongoing federal energy technology development programs. On the other hand, ERAB recommended that all of the programs in what it characterized as the "Technology Base" and which encompasses the Department of Energy's Basic Energy Sciences programs as well as some other more basic science programs should receive more funding or their funding should remain stable. (ERAB, 1983).

This major shift in the federal government's attitude toward energy R\&D is evident in Figure 3. After 1980, the significant growth of the "Other Energy R\&D” category denotes a growing preference for basic science designed to support more applied research over investment in applied research itself. As a result of sharp cuts in several applied R\&D program areas, this Other Energy R\&D / basic energy research category grew from approximately $20 \%$ to nearly $40 \%$ of all federal energy R\&D investments during this period. $^{7}$

\footnotetext{
${ }^{6}$ U.S. Secretary of Energy James Edwards before the Senate Energy and Natural Resources Committee, February 23, 1981, as quoted in Fehner and Hall, 1994.

${ }^{7}$ In 1994 President Reagan's second Secretary of Energy, Donald Hodel expanded upon this much more limited view of the government's role in developing energy technologies. Fehner and Hall, 1994, describe
} 
1989-1995: During the period 1989-1995, federal energy R\&D investments initially grew due predominantly to large but short-lived increases in federal efforts to develop clean coal technologies in order to address acid rain concerns. Yergin et al. (1995) estimate that between 1988 and 1995, the U.S. DOE spent slightly more than \$3 billion (in 2005 US\$) on clean coal technology demonstrations. By 1993, appropriations for these clean coal technology development programs were in rapid decline. However, support for basic energy research continued to grow continuing trends that began in the Regan Administration. By 1995, the Other Energy R\&D category (which was overwhelming composed of investments in basic energy sciences), comprised nearly $50 \%$ of all federal investments in energy R\&D. This was the first time that support for applied technology development energy $R \& D$ programs were the minority investment in the federal energy R\&D portfolio.

This continued preference for more basic energy science over applied energy technology development programs occurred even though the (first) Bush and Clinton

Administrations were clearly more inclined to see a larger role for the federal government in developing and helping to deploy commercial technologies as a means of helping to support the nation's economic competitiveness. For example during the Bush Administration, funding for energy efficiency R\&D increased substantially including commercially-oriented programs like the Advanced Battery Consortium to develop batteries for automobiles (Fehner and Hall, 1994). The Clinton Administration substantially increased funding and managerial focus geared towards demonstration and commercialization programs and in particular those focused on improving industrial energy efficiency and waste reduction (Fehner and Hall, 1994). The creation of the "Industries of the Future Program" in the mid-1990s which were collaborations between the federal government and a number of energy intensive industrial sectors is a clear break with the more limited mandate given to the DOE during the Reagan Administration of focusing on only those basic research and fundamental technology problems that the private sector would not do on its own.

1996-2008: While new programs were initiated during this period that were explicitly focused on developing technologies needed to address climate change such as Carbon Sequestration, the overall trend was one of level funding and continued preference for supporting more basic energy science, which in some years accounted for nearly $60 \%$ of all federal energy R\&D, at the expense of more applied energy technology development programs in this essentially zero sum funding environment. Investment in most program areas remained fairly constant throughout the period and modest growth in basic energy sciences largely fueled the small growth of the overall federal investment in energy R\&D.

Hodel's vision of one in which the DOE was to focus on "exploring the uncertain and expensive frontiers of energy science and technology... but should not build institutions to commercialize" the knowledge produced by the federal government's investments in this more speculative basic energy science. 


\section{Summary}

Over the nearly half century of federal support for energy R\&D documented here a couple of major overarching trends stand out:

- The role of nuclear energy R\&D within the federal energy R\&D portfolio has been greatly diminished over this time frame. In the 1960s, nuclear energy R\&D accounted for more than $70 \%$ of all federal energy R\&D, while over the past decade it has commanded approximately $10 \%$ of all federal energy $R \& D$ resources. There are several plausible explanations for this trend including a sense that in many ways nuclear power is a commercial technology and has been for some while as well as the waning interest in nuclear power that occurred as a result of the accidents at Three Mile Island and Chernobyl.

- While the federal government does now indeed support a more diversified energy R\&D portfolio than in the 1960 s, more than half of the current portfolio is comprised of basic energy research and related scientific research. Basic energy research is the only energy R\&D category in which investments have largely continued to grow over the entire past half century, while applied energy R\&D programs have more recently been declining and consistently command less priority in the federal energy effort.

While beyond the scope of this paper, it is also clear that individual program areas have undergone significant changes in focus in response to changing national needs. A clear example of this is the federal effort related to coal R\&D that was in the 1970s and early 1980s focused nearly exclusively on creating coal-based transportation fuels to a program that now has a significant focus on an explicitly climate mitigation technology like carbon dioxide capture and geologic storage. 


\section{Appendix 1: Description of Data}

The National Science Foundation reports overall federal R\&D expenditures by broad program area including energy R\&D starting with fiscal year 1961. Before 1961, federal $R \& D$ is simply broken down into defense and non-defense $R \& D$ expenditures. Starting with fiscal year 1969, the NSF reports total federal expenditures for energy R\&D as well as some detail on how these investments were spread out across major energy R\&D programmatic areas.

For the period 1961-1968, the analyst only has an overall accounting of the total amount spent by the federal government for all forms of energy R\&D. However a number of lines of evidence and source materials make it clear that the vast majority of federal investments in energy R\&D during the 1960s were devoted to nuclear energy. Before 1974, U.S. public sector support for energy R\&D was overwhelmingly focused on nuclear energy in an effort to develop safe and economic commercial nuclear reactors for the production of electricity (Stewart, et al., 1983).

Data presented here on three key large scale energy programs that were cornerstones of the national response to the energy crises of the 1970s and early 1980s were taken from the following sources:

- Cohen and Noll (1991) provide a detailed accounting of federal investments in synfuels program (1970-1984)

- Cohen and Noll (1991) provide a detailed accounting of federal investments in Breeder Reactors (1968-1985)

- Yergin et al. (1995) is the source for data on federal support for Large-Scale Solar Demonstrations (1978-1982)

The calculation of energy R\&D expenditures, as presented here, includes the budgets of several large DOE programs that collectively constitute the federal government's Basic Energy Science Program. These programs were formally removed from the Office of Management and Budget's "Energy R\&D" category (OMB budget category 270) and reclassified as "General Science" beginning in Fiscal Year 1998.

Data on the federal carbon sequestration program ${ }^{8}$ which began at a very low level in the late 1990s were taken from the detailed statistical tables for the U.S. Department of Energy's budget (DOE 2001 and DOE 2007 as well as annual versions of this same publication for the intervening years). Starting with fiscal year 2004, the budget reported here for the federal effort to develop sequestration technologies also includes support for the FutureGen program.

All other data on federal investments in energy R\&D are drawn from reports produced by the National Science Foundation which describe federal funding for energy R\&D and

\footnotetext{
${ }^{8}$ The U.S. Department of Energy's "carbon sequestration" program is overwhelmingly focused on the development of carbon dioxide capture and geologic storage technologies. Although this same program has supported some research related to terrestrial sequestration, terrestrial sequestration is a minor component of this program.
} 
specifically those programs that are contained within official Office of Management and Budget's "Energy R\&D (270)" budget function. Key references include NSF 1995 as well as the annual publication "Federal R\&D Funding by Budget Function" of which the most recent is NSF 2007. These data summarize all federal funding for nuclear energy $R \& D$, fossil energy R\&D, energy efficiency $R \& D$, renewable energy $R \& D$, and some research in the field of basic energy science. The Department of Energy funds the majority of the federal energy R\&D effort, although modest energy R\&D have and in some cases continue to be housed within the Tennessee Valley Authority, the Bonneville Power Administration, the Nuclear Regulatory Commission, the National Science Foundation and the Environmental Protection Agency. 


\section{Appendix 2: Key References}

Cohen LR and Noll RG. 1991. The Technology Pork Barrel. Brookings, Washington, D.C.

Congress of the United States. Office of Technology Assessment. (OTA 1975) "An Analysis of the ERDA Plan and Program October 1978. (NTIS order \#PB-250636). October 21, 1975

Council of Economic Advisors. 2006. Economic Report of the President: 2006. Appendix B Spreadsheet Tables. http://www.gpoaccess.gov/eop/tables06.html. Executive Office of the President. February 2006. Washington, D.C.

Energy Research Advisory Board. February 1983. The Federal Role in Energy Research and Development. A Report of the Energy Research Advisory Board to the United States Department of Energy. DOE/S-0016. Washington, D.C.

Fehner TR and Hall JM. 1994 Department of Energy 1977-1994: A Summary History. History Division. U.S. Department of Energy. November 1994. DOE/HR-0098.

Hammond AL, Metz WD, and Maugh TH. 1973, Energy and the Future. American Association for the Advancement of Science. Washington, D.C.

President Lyndon B. Johnson's Remarks Upon Signing the Air Quality Act of 1967 November 21, 1967. Lyndon Baines Johnson Library and Museum at the University of Texas. http://www.lbjlib.utexas.edu/johnson/archives.hom/speeches.hom/671121.asp

National Research Council. Committee on Benefits of DOE R\&D on Energy Efficiency and Fossil Energy. Board on Energy and Environmental Systems. Division on Engineering and Physical Sciences. 2001. Energy Research at DOE WAS IT WORTH IT: Energy Efficiency and Fossil Energy Research 1978 to 2000. National Academy Press. Washington, D.C.

National Science Foundation, Division of Science Resources Statistics. 2007. Federal R\&D Funding by Budget Function: Fiscal Years 2006-08. NSF 07-332. Richard J. Bennof, project officer. Arlington, VA.

National Science Foundation, Division of Science Resource Studies. 1997. Special Tabulation of data within the Energy R\&D (270) Budget Function requested by the author and provided Ronald Meeks. December 12, 1997.

Office of Management and Budget. 2006 Budget of the United States Government Fiscal Year 2007. Table 3.2-Outlays by Function and Subfunction: 1962-2011 http://www.whitehouse.gov/omb/budget/fy2007/hist.html. Washington, D.C. 
President's Committee of Advisors on Science and Technology (PCAST) 1997.Federal Energy Research and Development for the Challenges of the 21st Century. Executive Office of the President of the United States. November 1997.

Shultze, CL, Fried, ER, Rivlin, AM, and Teeters, NH. 1971. "Setting National Priorities for the 1972 Budget." Brookings Institution. Washington, D.C.

Stewart, WE, EH Stoddard, KK Geraci, and DK Ham. [Trends in Federal Support for Energy R\&D.] Division of Science Resource Studies. National Science Foundation. February 1983.

Yergin, D. et al. 1995. Energy R\&D: Shaping our Nation's Future in a Competitive World. Final Report of the Task Force on Strategic Energy Research and Development. June 1995. Secretary of Energy Advisory Board. U.S. Department of Energy. Washington, D.C.

U.S. Department of Energy. Office of Budget. 2007. U.S. DEPARTMENT OF ENERGY: FY 2008 Statistical Table by Appropriation. Washington, D.C. http://www.cfo.doe.gov/budget/08budget/Content/Approp_Stat.pdf

U.S. Department of Energy. Office of Budget. 2001. FY 2002 Budget Request to Congress. Statistical Table by Appropriation. Washington, D.C. http://www.cfo.doe.gov/budget/02budget/appstat.pdf

US Environmental Protection Agency. 2008. History of the Clean Air Act. http://www.epa.gov/air/caa/caa_history.html Last updated on Wednesday, January 30th, 2008.

United States Government Accountability Office. December 2006. Department of Energy: Key Challenges Remain for Developing and Deploying Advanced Energy Technologies to Meet Future Needs. GAO-07-106.

U.S. Government Printing Office. Public Law 90-148. The Air Quality Act of 1967. November 21, 1967. 